\title{
The German Greens in the 2017 Federal Elections
}

\author{
Wolfgang Rüdig, \\ School of Government and Public Policy, \\ University of Strathclyde, Glasgow, UK
}

Email: w.rudig@strath.ac.uk

On 24 September 2017, the German Greens achieved their second highest share of the vote (8.9\%) in a federal election but emerged the smallest opposition party in the Bundestag (67 of 709 seats). After coalition negotiations with the Christian Democratic Union (CDU) and Liberals (FDP) failed, the Greens continue in opposition. But, with a new, energetic leadership team elected in January 2018 and a continued strong presence in government at regional level, the place of the Greens in the German party system looks secure.

\section{Pre-campaign context}

Following the disappointing result of the 2013 federal elections, the Greens' post-election debate focused on how the party could again attain a role in federal government. Simple renewal of the 'red-green' coalition with the Social Democratic Party (SPD) seemed increasingly unlikely to be sufficient; with the SPD now struggling to poll above $25 \%,{ }^{1}$, the Greens clearly had to look for alternative coalition options.

The debate focused on two models: one, the so-called 'red-red-green' coalition with the SPD and the Left Party, seemed feasible now that, following the 2013 election, the SPD leadership had abandoned its previous opposition to a coalition with the Left Party; the second, a so-called 'blackgreen' coalition with the CDU and its Bavarian sister party, the Christian Social Union (CSU), an idea mooted for some time, particularly given the move to the centre under Angela Merkel's leadership, which had seen the CDU adopting 'green' policies on phasing out nuclear power and other issues. After the 2013 election, there was a majority for such a 'black-green' coalition, but after preliminary talks, the Greens abandoned this effort, partly out of concern that such a coalition would alienate some members and voters.

Given the strong role of regional government in the German system, developments in some key states provided an important background to the discussion of coalition options. In 2014, the first 'red-red-green' coalition was formed in the small East German state of Thuringia, followed in 2016 by a 'red-red-green' coalition in the city-state of Berlin. These two examples were more than matched, however, by rather more significant coalitions between the Greens and the CDU in Hesse

\footnotetext{
${ }^{1}$ For polling data as well as federal and regional election results, see www.wahlrecht.de
} 
and Baden-Württemberg. The Hesse 'black-green' coalition, formed in 2013, proved to be stable and successful. More notable was the 'green-black' coalition in Baden-Württemberg where the Greens had led a 'green-red' coalition since 2011, with Winfried Kretschmann elected as the first Greens First Minister; the Greens increased their vote share in 2016, polling $30.3 \%$ (compared with $24.2 \%$ in 2011), to become the largest party in the state, resulting in a 'green-black' coalition with Kretschmann re-elected as First Minister with CDU support.

Before the beginning of the 2017 election campaign, the idea of a 'black-green' coalition had thus gained some support, both among Greens and CDU politicians and supporters. The 'red-red-green' project, on the other hand, had been pushed more into the background, particularly as the Left Party was deeply divided on the issue, with open factional infighting raising doubts whether it could be a reliable coalition partner.

The Greens again decided by a ballot of all party members to elect two 'lead candidates' (Spitzenkandidaten) to spearhead their election campaign. As at least one of the lead candidates had to be female, with only one woman candidate, parliamentary co-leader Katrin Göring-Eckhardt, the contest was effectively between the three male candidates. The 'left' faction was represented by Anton Hofreiter, parliamentary co-leader, and the other two were seen as 'Realo' candidates: Cem Özdemir, party co-leader since 2008, and Robert Habeck, Environment Minister in the 'redgreen'government in Schleswig-Holstein. The membership vote announced in January 2017, saw Özdemir elected with 35.96\%, narrowly beating Habeck (35.74\%), with Hofreiter third with $26.19 \%$, which possibly indicated members' openness to considering a 'black-green' coalition.

\section{The Election Campaign}

The early phase of the campaign was dominated by the SPD's decision to select Martin Schulz, former president of the European Parliament, as its new leader and 'Chancellor candidate'. Schulz initially proved extremely popular, and the SPD's poll rating rose to around 30-33\% in March 2017, some $10 \%$ higher than in January. The 'Schulz effect' was bad news for the Greens. Having polled in excess of $10 \%$ thoughout 2016 , several opinion polls now put them as low as $6 \%$, raising fears that the party might even struggle to pass the $5 \%$ threshold required for representation in the Bundestag.

Three regional elections took place in spring 2017, which proved to have an important effect on the campaign. The Saarland election in March provided a turning point when initial hopes for the SPD to replace the CDU as largest party were dashed. More bad news for SPD and Greens followed in May when the 'red-green' coalition was comprehensively beaten in North Rhine-Westphalia, Germany's most populous state, with Green support almost halved to $6.4 \%$. Here, reform of the education system, spearheaded by the Greens, had proved very unpopular. A far better result had been achieved a week earlier in Schleswig-Holstein where a 'red-green' coalition had also governed since 2012; here the SPD lost votes and power, but the Greens, benefitting from the popularity of its green environment minister, Robert Habeck, were almost unchanged with $12.9 \%$. Consequently, , the Greens remained in government in a new 'Jamaica' coalition of the CDU (black), FDP (yellow) and the Greens. Habeck's success in negotiating this new coalition boosted his standing nationally, and the idea that a 'Jamaica' coalition might also be a model for the federal level gained ground. 
These state election results were particularly damaging for the SPD as the popularity boost provided by the Schulz candidacy seemed to have lost its initial momentum. By summer 2017, the SPD had slumped to its pre-'Schulz effect' level, which seemed to help the recovery of the Greens' poll rating, which stabilised at around $8 \%$ in the months before the election. However, it was clear that both a 'red-green' and a 'red-red-green' coalition would fall far short of a majority. Yet, the rise of the populist right-wing Alternative for Germany (AfD) suggested that the 'black-green' coalition would also fall short, with the'Jamaica' coalition emerging the only possible alternative to continuation of the 'grand coalition'.

The Green campaign avoided aiming for any specific coalition. The refugee issue dominated much of the campaign. The Greens supported the government on this issue, with Merkel continuing to be very popular among Greens voters. The Greens joined the SPD in attacks against the AfD, but struggled to find a strong theme of their own. Climate change, phasing-out coal, promoting alternative energy, and reforming agriculture were highlighted, but a big issue to mobilise more people to vote Green was missing. Potentially, the 'Dieselgate' scandal, implicating several German automobile companies in fraudulent attempts to hide their vehicles' high emission levels, might have played this role; the Greens demanded that local authorities should have the right to ban diesel cars entering polluted town centres and to allow the new registration only of electric cars after 2030. However, only $27 \%$ of the public approved, and $67 \%$ opposed, phasing-out cars with combustion enginges by 2030 (Forschungsgruppe Wahlen 2017, p. 39). Moreover, the party faced internal division on the issue with First Minister Kretschmann, who had built a close relationship with the powerful car industry in his state, opposing the proposal to ban petrol and diesel cars by 2030, which made it difficult for the Greens to pursue the issue more aggressively.

\section{The Result}

The mood of the Greens before election day was apprehensive. Final poll predictions placed the Greens between 7 and $8 \%$, but in previous elections the Greens had often underperformed on election day. So it came as a surprise and relief when the result $-8.9 \%$ - was second only to the 2009 result of $10.7 \%$. The joy was somewhat diluted by the Greens ending up the smallest parliamentary group in the Bundestag, outpolled by the Left, FDP and AfD.

The analysis of voting behaviour by the major polling institutes suggested that the Greens particularly benefitted from the support of former SPD voters and new voters. Nevertheless, in social background and geographical spread, Greens voters displayed continuity: Greens were particularly popular amongst those with a high education level working in the public sector, and in university towns, but weak in eastern Germany (Forschungsgruppe Wahlen 2017; infratest dimap 2017).

Analysis of the age structure in historical context, using official figures (Bundeswahlleiter 2018), provides some interesting insights. While voting Green was proportionately higher among younger

\footnotetext{
${ }^{2}$ All figures on the age and gender of Green voters are based on a special survey carried out by the Federal Statistical Office on the basis of marked ballot papers with actual votes cast (Bundeswahlleiter 2018). For a previous analysis of data from this source and more detailed description of the methodology, Cf. Rüdig 2012.
} 
age groups, support among some older voters was actually far more important in contributing to the overall share of the Greens vote. The age structure of the German population means older voters have an increasingly important role: those aged between $18-24$ only represented $8 \%$ of the German electorate in 2017 compared with the $45-59$ bracket's $28.6 \%$ and $36.3 \%$ for the $60+$ age group. Consequently, only $11.4 \%$ of all Green voters were aged $18-24$ as compared with $33.8 \%$ who were aged $45-59$ and $20.9 \%$ who were over 60 . In short, over half of all Greens voters were aged 45 or older. While the Greens are still successful in attracting younger voters, their importance is limited by the relatively small size of younger cohorts. A major factor behind continued Greens success is their ability to retain the support of a significant share of older voters, which may in part reflect continuing support from the political generation defined by the 'new social movements' of the 1970s and 1980s.

---Figure 1 about here ---

Figure 1 shows changes in the Greens vote among different age groups since the Greens first participated in a federal election in 1980. Almost 70\% of Greens voters in 1980 were aged under 35, compared with less than $30 \%$ since 2000 ; Greens voters aged 45 or older were a small minority up to 1990, but have become a majority since 2013. Another long-term trend continued in 2017 is the rising share of female voters: while less than $50 \%$ of Greens voters in the 1980 s were women (Rüdig 2012, p. 114), their share has risen steadily to reach 59\% in 2017.

\section{Post-Election Developments}

The election result left only two feasible coalition options. One was the continuation of the CDU/CSU - SPD 'grand coalition', but Schulz declared on election day that the SPD was not prepared to continue in coalition and was going into opposition. The other option was a 'Jamaica' coalition between CDU/CSU, FDP and Greens. Widely discussed beforehand, it would still be a difficult step for the Greens, and there was considerable scepticism among party members about such a project, particularly given the large policy differences with the FDP as well as the CSU. Coalition talks dragged on for several weeks, eventually ending in failure in late November after the FDP walked out. The SPD was eventually persuaded to change its mind, and after a rather tortuous process, a new 'grand coalition' was formed in March 2018.

The failure of 'Jamaica' coalition talks was disappointing for the Greens leadership, but it avoided potentially divisive internal debates and controversies. Both party co-leaders, Cem Özdemir and Simone Peter, stood down, and a new leadership team was elected at the party conference in January 2018. Robert Habeck emerged as the new green 'superstar', with the party congress bending backwards to amend the party constitution to allow him to continue as environment minister in Schleswig-Holstein for a transition period. While Habeck's election, with $81 \%$ of delegate votes, looked a foregone conclusion, the election of the second, female, co-leader was contested by candidates representing the two main factions of the party. The candidate more associated with the Realo wing, Annalena Baerbock, impressed delegates most, and against a long-established tradition of both wings of the party being represented among the party co-leaders, Baerbock was elected. Some commentators saw this as a major shift of the party to the right, but most Greens of the 'left' faction seemed fairly relaxed about it; indeed, both Baerbock and Habeck took positions in their 
leadership campaigns that appealed to left-wing Greens. After the first few months in office, 'left' members continued to be 'enthused' by the new leadership (Schulte 2018). Greens membership reached a record 65,257 members at the end of 2017. By June 2018, in the polls, the party is in double figures again, and the Greens were still represented in 9 out of 16 regional governments. The 'grand coalition' does not command a majority in the upper chamber, the Bundesrat, so it will regularly require the support of regional governments involving the Greens, which puts them in quite a strong position to influence federal legislation on important matters.

Despite these indications of stability and continuity, it is still very unclear how the party might find a way back into federal government. With potentially major changes in both CDU/CSU and SPD in coming years, the shape of the German party system seems unusually unpredictable, providing new challenges but also new opportunities for the Greens.

\section{Acknowledgements}

I am grateful to the German Academic Exchange Service (DAAD) and the International Association for the Study of German Politics (IASGP) as well as Dan Hough (University of Sussex) for organising the Berlin election trip that allowed me to attend briefings by party campaigners as well as observe election rallies in September 2017. I also thank E. Gene Frankland (Ball State University) and other observers for helpful discussions on green politics in Germany.

\section{References}

Bundeswahlleiter (2018), Wahl zum 19. Deutschen Bundestag am 24. September 2017, Heft 4: Wahlbeteiligung und Stimmabgabe der Frauen und Männer nach Altersgruppen (Wiesbaden: Der Bundeswahlleiter, Statistisches Bundesamt).

Forschungsgruppe Wahlen (2017) Bundestagswahl: Eine Analyse der Wahl vom 24. September 2017 (Mannheim: Forschungsgruppe Wahlen e.V.).

Infratest dimap (2017) WahlREPORT Bundestagswahl: Eine Analyse der Wahl vom 24. September 2017 (Berlin: infratest dimap).

Rüdig, W. (2012) 'The perennial success of the German Greens', Environmental Politics, 21(1), pp. 108-130.

Schulte, U. (2018) 'Grünes Spitzenpersonal: Absteiger wider Willen', Die Tageszeitung (online), 2 May 2018, http://www.taz.de/!5499412/ [accessed 7 June 2018] 
Figure 1: German Greens voters by Age and Gender, Federal Elections 1980-2017

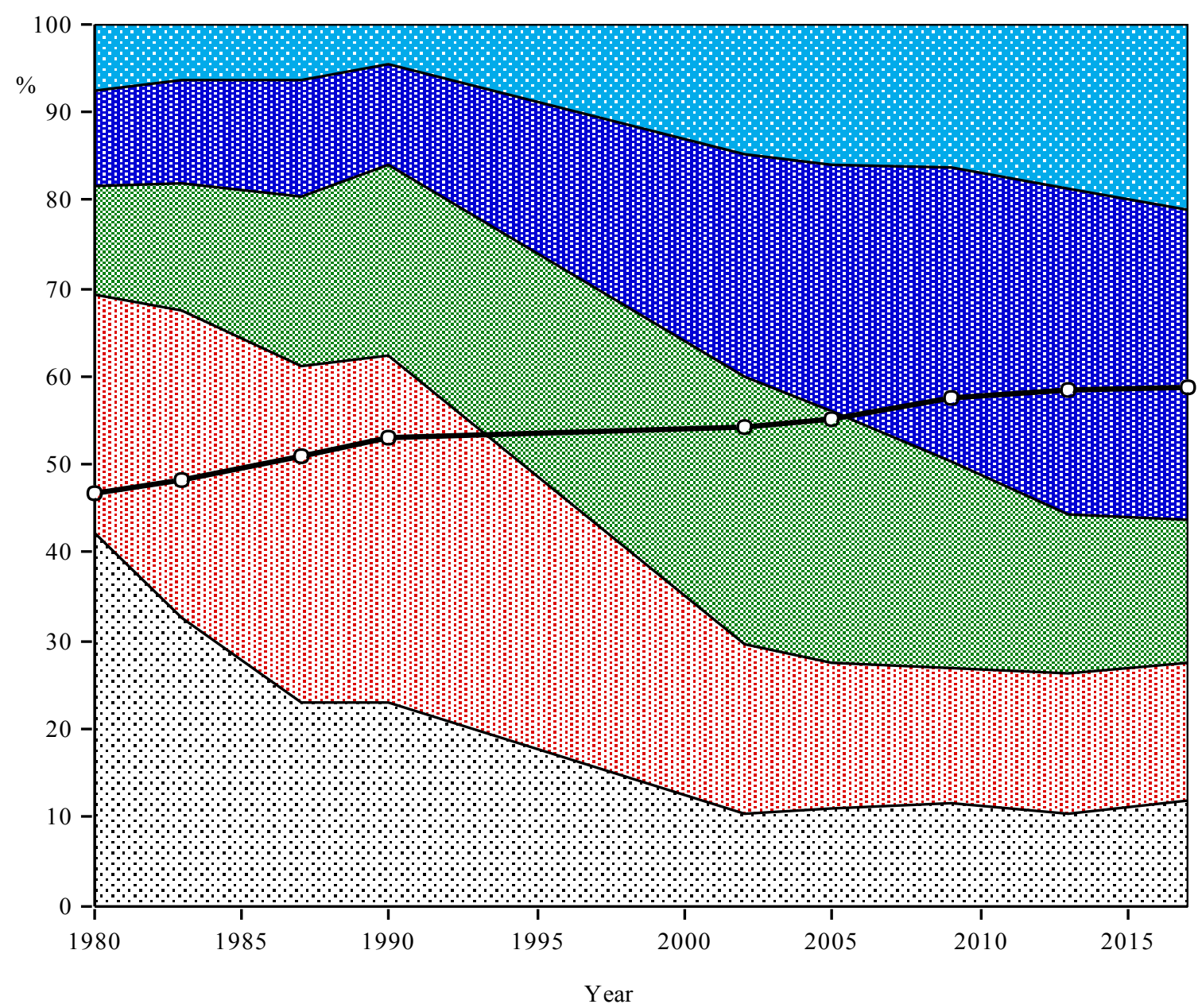

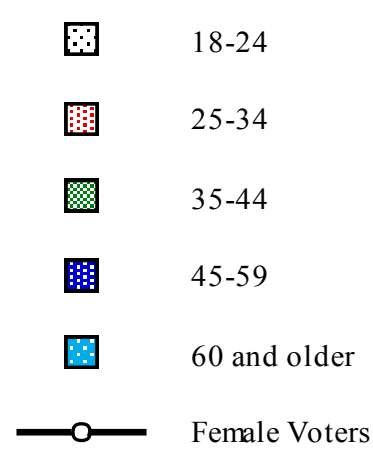


Source: Author's own calculations, based on Bundeswahlleiter (2018). Data for 1980, 1983 and 1987 refer to elections in West Germany only, data for 1990 , 2002, 2005, 2009, 2013 and 2017 to the unified Germany. The survey was not conducted in 1994 and 1998. 